\title{
Rainwater Harvesting with Subsequent First Flush: Water Quality Performance for Non- Potable Purpose
}

\author{
Nurul Faradila binti Sambas, Lavania Baloo, AP. Zahiraniza Mustaffa
}

\begin{abstract}
In the framework of enhancing water resource management, the Rainwater Harvesting (RWH) system has been recognized as one of the potential solution to mitigate water crisis issues. This paper aimed to study the water quality analysis of RWH system with subsequent flushes devices; in terms of its efficiency and practicality for non-potable purposes such as irrigation and toilet flushing. The project is also meant to identify the ideal volume among the five (5) FF devices installed; to be flushed away in order for the harvested rainwater to be usable for non-potable activities (i.e. irrigation, industry and toilet flushing). A RWH model were mounted on a wall of an existing store building at Universiti Teknologi PETRONAS (UTP), Perak. A total of eight (8) rain events (set of readings) were analysed. The nine (9) parameters monitored are: $\mathrm{pH}$, turbidity, dissolved oxygen (DO), total suspended solids (TSS), total coliforms (TC), chemical oxygen demand (COD), total nitrogen (TN), ammonia and nitrate. For physical water quality parameters; $\mathrm{pH}$, turbidity, $D O$ and TSS, the final reading ranges were 4.60 8.37, 0.41 1.52 NTU, 7.60 9.44 $\mathrm{mg} / \mathrm{L}$ and $0 \sim 40 \mathrm{mg} / \mathrm{L}$, respectively. Chemical parameters such as COD, TN, ammonia and nitrate were in the ranges of 0 32 $\mathrm{mg} / \mathrm{L}, 4 \sim 12 \mathrm{mg} / \mathrm{L}, 0.11 \sim 0.95 \mathrm{mg} / \mathrm{L}$ and $0 \sim 1.4$ $m g / L$, respectively. Meanwhile the biological parameter which is the TC was in the range between 0 358.5 MPN. Based on the calculations, it is deduced that a minimum of $1.02 \mathrm{~mm}$ of rainfall of total $10.5 \mathrm{~mL}$ from FF1 to FF3 is needed to be flushed away; ensuring only better quality of rainwater being stored. The FF method is very important in the application of RWH system because it diverted the first flow of rainfall that is expected to be the most contaminated. The RWH system with subsequent FF devices is suitable for non-potable purpose. Upon further treatment and model modification, the harvested rainwater shall fit for potable use.
\end{abstract}

Index Terms: Subsequent first flush, hydraulic model, rainwater harvesting, environmental engineering

\section{INTRODUCTION}

Water is the foundation of life; and Malaysia can be categorized as a tropical country blessed with abundance of water resources including rainfall throughout the year [1]. Yet, the country still facing several water rationings in certain affected states [2]. To mitigate the present and future water crisis; rainwater harvesting (RWH) system have been indicted as one of the potential solution since 1999.

Revised Manuscript Received on June 22, 2019.

Nurul Faradila binti Sambas, Universiti Teknologi, PETRONAS Dr. Lavania Baloo, Universiti Teknologi PETRONAS

AP. Dr. Zahiraniza Mustaffa, Universiti Teknologi PETRONAS
In receiving billions metre cube of rainfall each year, Malaysia is well-apt to fully implementing the system [3]. The purpose of RWH system is basically to save on treated and supplied water [4]. A simple RWH can only collects the rainwater without treating it, but by installing a FF device, the water quality of rainwater harvested was observed to improve [5, 6]. Despite of its pure and distilled characteristic, quality of rainwater could be jeopardized due to surrounding gas emission and contaminations from the contact with catching materials [5, 7, 8, and 9].

Rainwater Harvesting (RWH) system is generally defined as the direct collection of rainwater from roofs and other purpose built catchments [10]. In addition, RWH is the method of capturing storm water runoff, typically from a rooftop and storing it in a tank for future use [11]. On the other hand, RWH is the source of control solutions where it became the complementary supply water method to support the potable water saving [12]. RWH is also recognized as an effort to reduce the impact of climate change on water supplies [13]. RWH has been indicted in Malaysia since 1999 preceded by 1998 drought. The Guidelines for Installing a Rainwater Collection and Utilization System was established by the Minister of Housing and Local Government to encourage the implementation of RWH in tackling water shortages in the future $[14,15]$.

Other than Malaysia, it has been reported that RWH has been implemented and significantly promoting water saving in residences in different countries such as Germany, Austria, Brazil, Genoa (Italy), North Carolina (United States), Jordan, Abeokuta (Nigeria), Seoul (South Korea), Granollers (Spain), South East (England) and Ireland [5, 14]. In economically basis, there is no strategy is cost efficient if average domestic regional water prices are considered [16]. However, RWH does not need chemical, physical nor biological treatment; resulted in minimal running and maintenance cost comparable to centralized water supply system [17]. The capital cost of RWH might be significant, however the long-term operation cost and maintenance are reasonable depends on the type of catchment, conveyance system, tank size and storage material [5].

\section{WATER CRISIS IN MALAYSIA}

In 2016, Malaysia's per capita water consumption is considered unsustainable compared to the recommendation of $165 \mathrm{~L} / \mathrm{c} / \mathrm{d}$ by WHO. This issue is of significant concern and has been compounded by recent weather events [18].

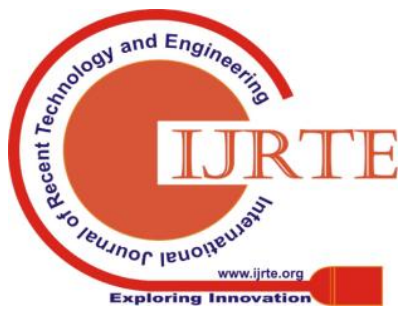


The recorded water consumption by Malaysian from 2013 to 2016 was presented as below [19]:

\section{WATER CONSUMPTION BY} MALAYSIAN

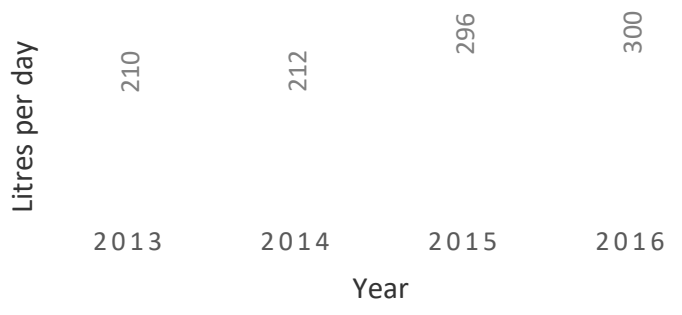

Fig. 1 Water consumption in Malaysia

In 31st July 2018, the Department of Statistic Malaysia (DSM) has released a statically data in a press conference; recording the current population of Malaysia is 32.4 million lives in the second quarter of 2018 [20]. This showed a rapid population growth since 2012 whereby the increment of $10 \%$ is recorded. Although Malaysia is blessed with abundance of water resources, the country still not able to avoid the water shortage issue that lead to water rationing each year. The most common affected area every year is Klang Valley, Selangor and Pahang [22, 23, 24, 25]. According to DID / JPS Malaysia (2012), Malaysia is also facing the risk of climate change effect threats in the future. The global warming effects around the world is causing the sea level to rise (SLR) about 0.1 to $0.13 \mathrm{~cm}$ per year and causing 20 to $40 \%$ faster river flow by 2100 based on NAHRIM's study [25]. Water supply crisis is possible due to several causes such as:

i. Uneven rainfall seasonal distribution

ii. Extended period of draughts or hot weathers due to climate change

iii. Growing demand and high consumption due to population growth

iv. Extensively deforestation that affects groundwater infiltration and retention

v. Water resources pollution that limiting water usability

\section{METHODS}

In order to assess the practicality of RWH system with subsequent flushes effect to harvested rainwater quality, the overall project activities for this case study were divided into 5 different stages:

1. Identifying the sampling location and its model

2. Samples collection at certain rain intensity

3. Analyzing the water quality analysis on physical, chemical and biological properties of rainwater harvested

4. Data interpretation and analysis

5. Reports on findings

\section{A. Model}

The model has been set up on August 2017, mounted on the wall of a facility building across to Block N, UTP. Figure 2 and 3 are showing the model set-up and brief flow diagram on how the system works.

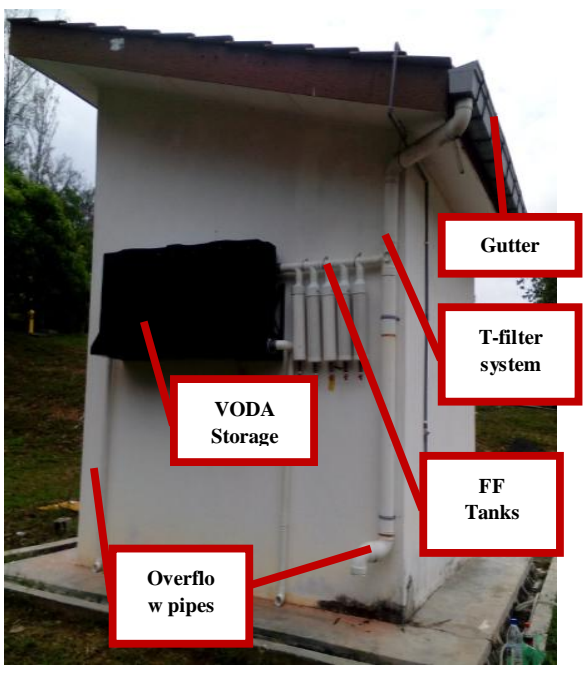

Fig. 2 RWH model set-up

\section{B. Roof catchment area calculation}

Each of First Flush collection tanks will provide us with 3.5 litre to be consider full capacity. The total storage for all

5 First Flush collection tanks are as shown:

Volume for collection tanks, $\mathrm{m}^{3}$

$=3.5$ litre $x 5$ bottles

$=17.5$ litre $=0.0175 \mathrm{~m}^{3}$

Meanwhile, the dimensions of the roof is $3.49 \mathrm{~m} \times 5.20$ $\mathrm{m}$, and the roof was elevated at 35 degrees. The required rainfall $(\mathrm{mm})$ to fill up 5 First Flush tanks is calculated as follow:

Where,

Roof catchment area, $m^{2}$

$=($ length,$m) \times($ width,$m) \times(\sin \theta$ of roof $)$

$=3.49 \mathrm{~m} \times 5.20 \mathrm{~m} \times \sin 35^{\circ}$ of roof

$=10.42 \mathrm{~m}^{2}$

And,

Rainfall, $m m$

$=\frac{\text { Volume of rainwaterin storage,m33 }}{\text { Roof catchment area,m2 } 2} \times 1000$

$=\frac{0.0175 \mathrm{m3}}{10.42 \mathrm{~m} 2} \times 1000$

$=1.68 \times 10^{-3} \mathrm{~m}=1.68 \mathrm{~mm}$

From the calculation above, we can conclude that to have all 5 samples, with the roof catchment area of $10.42 \mathrm{~m}^{2}$, the rainfall captured is no less than $1.68 \mathrm{~mm}$. The rainfall captured for one collection tanks is $0.34 \mathrm{~mm}$ (3.5 liters).

\section{Samples handling}

Collection: The samples of water are collected from the collection tanks; labelled as S1 to S5 (1 litre each bottle). The samples are collected once a week (depending on rain intensity).

Preservation: Few parameters need to analyse within 24 hours retention time, which are: $\mathrm{pH}$, Dissolved Oxygen, Turbidity, Total Coliform, Total Suspended Solid and Chemical Oxygen Demand. Ammonia, Nitrate and Total Nitrogen could be assessed within 28-hours retention time. The samples are kept in the cold room in the Environmental Engineering Laboratory for quality preservation.

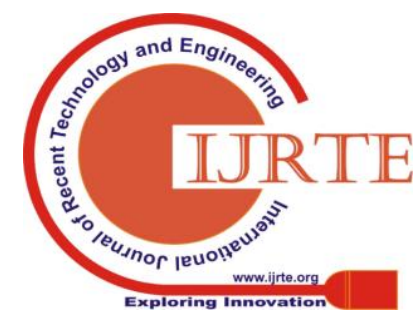




\section{RESULT \& DISCUSSION}

The following Table 1 and Table 2 are representing the sampling frequencies and average parameters analyzed, within the duration of October 2017 to February 2018; consisting of 8 set of readings in total. These readings is comparing the functionality of the model during dry and rainy season. The project location was experiencing quite dry season during October - November 2017 and on February 2018; while having rainy season from November December 2017. Parameters of $\mathrm{pH}$ and nitrate are not discussed in detail as they indicated constant result throughout the subsequent flushing.
Table. 1 Sample collection days

\begin{tabular}{|l|l|l|}
\hline Date of collection & Rain intensity & Tiles condition \\
\hline $\begin{array}{l}16^{\text {th }} \text { and } 30^{\text {th }} \\
\text { October } 2017\end{array}$ & Low rain intensity & Dry and dirty \\
$12^{\text {th and } 19^{\text {th }}}$ & Daily raining & $\begin{array}{l}\text { Cleaned due to } \\
\text { continuous runoff } \\
\text { November } 2017 \\
03^{\text {rd and } 10^{\text {th }}}\end{array}$ \\
$\begin{array}{l}\text { December } 2017 \\
22^{\text {nd }} \text { and } 26^{\text {th }}\end{array}$ & Daily raining & $\begin{array}{l}\text { Leaned due to } \\
\text { continuous runoff }\end{array}$ \\
February 2018 & & Dry and dirty \\
\hline
\end{tabular}

Table. 2 Parameters analysis from 8 sets of readings

\begin{tabular}{|l|c|c|c|c|c|c|}
\hline \multirow{2}{*}{ Parameters } & \multicolumn{5}{|c|}{ Average value from October 2017 to February 2018} \\
\cline { 2 - 7 } & FF1 & FF2 & FF3 & FF4 & FF5 & MDWQS \\
\hline $\begin{array}{l}\text { Total Suspended } \\
\text { Solids/TSS }(m g / L)\end{array}$ & 26.4 & 24.5 & 17.7 & 16.9 & 13.9 & - \\
\hline $\begin{array}{l}\text { Total Coliform / TC } \\
(M P N)\end{array}$ & 118.2 & 99.6 & 89.8 & 82.1 & 72.2 & 0 \\
\hline $\begin{array}{l}\text { Chemical Oxygen } \\
\text { Demand/COD (mg/L) }\end{array}$ & 9.9 & 9.5 & 7.6 & 7.6 & 6.0 & - \\
\hline Ammonia (mg/L) & 0.6 & 0.6 & 0.6 & 0.5 & 0.5 & 1.5 \\
\hline $\begin{array}{l}\text { Total Nitrogen / TN } \\
(m g / L)\end{array}$ & 7.4 & 6.1 & 7.2 & 6.9 & 7.0 & - \\
\hline Turbidity (mg/L) & 0.9 & 1.0 & 0.9 & 0.9 & 0.8 & 5 \\
\hline $\begin{array}{l}\text { Dissolved oxygen / DO } \\
(m g / L)\end{array}$ & 8.3 & 8.0 & 8.3 & 8.5 & 8.6 & - \\
\hline
\end{tabular}

Notion on contaminated tanks: during the installation process, the FF tanks were being glued permanently to the flow pipe which made it as a closed loop system and hard for scheduled maintenance. Following the closed loop system default, FF2 is suspected to be contaminated since November 2017 based on the readings till February. However, due to the shortage of research time and full schedule, the readings are kept as they have been obtained instead of re-installing the system. On March 2018, a clump of moss or algae was found in the FF2. This validate the assumption of the FF2 is contaminated. The algae started to grow in the tank during the hot and cold weather and started to become loose in March.

TSS: Samples collected on 19 November recorded the overall minimum TSS value amongst all collection day. However, the highest maximum value of $40 \mathrm{mg} / \mathrm{L}$ is still within the range of rainwater quality in storage tank standard by NAHRIM, which is between 14 to $126 \mathrm{mg} / \mathrm{L}$. Therefore, it is can concluded that the harvested rainwater containing an optimum TSS value.

TC: The highest value recorded on October 2017 was still under the range of allowable number for irrigation and toilet flushing purpose. Therefore, it is can concluded that the harvested rainwater is appropriate for non-potable but certainly harmful for drinking without proper treatment first.

COD: Samples collected on rainy season (December 2017) recorded the lowest COD content meanwhile the highest content noted on October 2017 (dry season). The highest value of $32 \mathrm{mg} / \mathrm{L}$ is still within the range for irrigation water quality standard. It is concluded that with continuous raining flow, the sample collected will be suitable for non-potable purpose.

Ammonia: The highest value $(0.95 \mathrm{mg} / \mathrm{L})$ is exceeding the rainwater quality in storage tank standard by NAHRIM which is between $(0.02$ to $0.18 \mathrm{mg} / \mathrm{L})$. However, it is under the range for Raw Water, safe for human body contact, irrigation and industrial purpose. Therefore, it is can concluded that the harvested rainwater containing a safe ammonia content for non-potable purpose.

TN: The samples collected on December recorded the lowest value of TN indicating the water is cleaner, while the highest value recorded during November. The highest value of $12 \mathrm{mg} / \mathrm{L}$ is exceeding the water quality standard for agriculture, that is $10 \mathrm{mg} / \mathrm{L}$. Therefore, it is can concluded that the harvested rainwater contains excess nutrients from the decomposition of insects or birds on the rooftop.

Turbidity: The samples collected during dry season (Oct 2017) were the most turbid among others while the clearest water recorded through samples collected during rainy season (Nov-Dec 2017). The highest value of $1.52 \mathrm{NTU}$ is still within the range of water quality standards referred.

Published By:

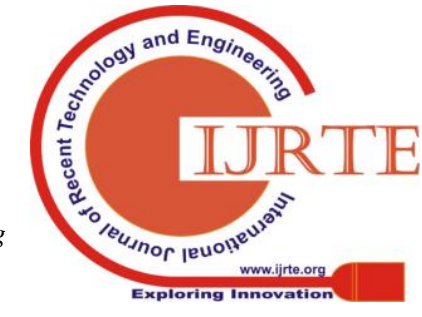


Therefore, it is can concluded that the harvested rainwater containing an optimum turbidity value that suitable for nonpotable purpose.

DO: The maximum value recorded as $9.44 \mathrm{mg} / \mathrm{L}$ on $30^{\text {th }}$ October is exceeding the range of rainwater quality in storage tank standard by NAHRIM; yet is still suitable for industrial and irrigation purpose. The lowest values recorded during December 2017 while the highest recorded during November 2017

\section{CONCLUSION}

Based on the results and data analysis, it can be concluded that the quality of rainwater harvested varies from storage to storage; affected mainly by the quality of surrounding air and roof tiles conditions as well as rainfall that determines how many flushes that could be obtained. It was noted that, even though the quality of harvested rainwater after the fifth flushes still not meeting the requirement of drinking, but the parameters showed that the water are appropriate enough for human contact and others non-potable activities. From the analysis as well, flushes up to the third tank (FF3) is enough to reach a safe quality for human contact. For recommendation, it is advisable to conduct schedule maintenance to the system for better results. Further research and treatment are needed on heavy metal analysis and bacteriological characteristics of the rainwater if we are aiming for drinking water purpose.

\section{ACKNOWLEDGMENT}

The research was funded by Universiti Teknologi PETRONAS under Civil and Environmental Engineering Department.

\section{REFERENCES}

1. 'Iklim Malaysia'. (2017). Malaysian Meteorological Department. Retrieved (2017). Malaysian Meteorological Department http://www.met.gov.my/web/metmalaysia/118?doAsUserId=LKnQ9m VxawU\%3D

2. “Beberapa kawasan di lembah Klang terjejas bekalan air". (2018, Mar 03). Berita Astro Awani. Retrieved from http://www.astroawani.com/berita-malaysia/beberapa-kawasan-dilembah-klang-terjejas-bekalan-air-169487

3. Department of Irrigation and Drainage Malaysia (DID), (2010). Rainwater Harvesting System. Retrieved from http://www.water.gov.my/our-services-mainmenu-252/urbanstormwater/sistem-penuaian-air-hujan-spah-mainmenu-965?lang=en.

4. Atsali, G., Katrinakis, D., Panagiotakis, S., Despina, A., Kalochristianakis, M., Manios, T., and Malamos, A., (2013). First Flush rainwater harvesting application with Fuzzy Logic control. Technological Educational Institute of Crete, Heraklion, Greece.

5. Fayez A. A. \& A. W. Al-Shareef. (2008), Roof rainwater harvesting systems for household water supply in Jordan. Desalination, 243, 195 207. Retrieved from http://www.sciencedirect.com/science/article/pii/S0011916409002677

6. Martinson, D. B. and Thomas, T. H., (2009). Quantifying the First Flush Phenomenon: Effects of First-Flush on water yield and quality.

7. Ariyananda, T.N. 1999. Rainwater Harvesting for Domestic Use in Sri Lanka, $25^{\text {th }}$ WEDC Conference. Ethiopia: Addis Ababa, Ethiopia, 369. 372 .

8. Coombes, P.J., Argue, J.R., Kuczera, G., (1999). Figtree place: a case study in water sensitive urban design (WSUD). Urban Water 1, 335343

9. Vasudevan P. ,Tandon M., Krishnan C. and Thomas T. (2001). Bacteriological Quality of Water in DRWH. Proceeding of workshop on Rain water harvesting, IIT Delhi, April 2001.
10. Che-Ani A.I., Shaari N., A. Sairi., M. F. M. Zain. \& M. M. Tahir. (2009). Rainwater Harvesting as an Alternative Water Supply in the Future. European Journal of Scientific Research, 34, 132-140. Retrieved from https://www.researchgate.net/profile/A_CheAni/publication/237821822_Rainwater_Harvesting_as_an_Alternative _Water_Supply_in_the_Future/links/00b4952def39b1b6c4000000

11. Jones M. P. \& Hunt W.F. (2009). Performance of rainwater harvesting systems in the southeastern United States. Resources, Conservation and Recycling, 53, 623-629. Retrieved from http://www.sciencedirect.com/science/article/pii/S0921344909002547

12. Athavale, R.N. (2003). Water harvesting and sustainable supply in India. Environment \& Development Series, India: Centre for Environment Education. Retrieved from https://books.google.com.my/books?id=bxK7ahcY1WsC\&pg=PA320 \&lpg=PA320\&dq=Water+harvesting+and+sustainable+supply+in+Indi a.+Environment+\%26+Development+Series,+India

13. Palla A., Gnecco I., \& Barbera P. L. (2017). The Impact of Domestic Rainwater Harvesting Systems In Storm Water Runoff Mitigation At The Urban Block Scale. Journal of Environmental Management, 191 297-305. Retrieved from http://www.sciencedirect.com/science/article/pii/S0301479717300439

14. Aladenola O. O. \& Adeboye O. B. (2009). Assessing the Potential of Rainwater Harvesting. Water Resource Manage, 24, 2129-2137. Retrieved from http://www.springerlink.com/index/7T341503618JW51L.pdf

15. Ministry of Housing and Local Government (MHLG), (2008) Guidelines for Installing a Rainwater Collection and Utilization 1999 Edited by: MHLG. Unpublished article. [15] Farreny R., Gabarrell X. \& Rieradevall J. (2011). Cost-efficiency of rainwater harvesting strategies in dense Mediterranean neighbourhoods. Resource, Conservation and Recycling, 55, 686-694. Retrieved from http://www.sciencedirect.com/science/article/pii/S0921344911000103

16. Water Resources Agenda in Malaysia (2012, Nov 26) Department of Irrigation and Drainage Malaysia. Malaysia Water Resources Management Forum 2012.

17. Farreny R., Gabarrell X. \& Rieradevall J. (2011). Cost-efficiency of rainwater harvesting strategies in dense Mediterranean neighbourhoods. Resource, Conservation and Recycling, 55, 686-694. Retrieved

from http://www.sciencedirect.com/science/article/pii/S0921344911000103

18. Lee J.Y., Yang J.S., Han M. \& Choi J. (2010). Comparison of the microbiological and chemical characterization of harvested rainwater and reservoir water as alternative water resource. Science of the Total Environment, 408, 869-905. Retrieved from http://www.sciencedirect.com/science/article/pii/S0048969709010894

19. 'Malaysian water industry', (2016). Retrieved from https://www.export.gov/article?id=Malaysia-Water-Industry

20. 'Work together to resolve water issues' (2016, Apr 7) New Straits Times.Retrievedfromhttp://gedung1 nahrim.nahrim.gov.my/WebPages/ ViewReport.aspx $?$ met $=$ RP\&smet $=W R \& a p p I D=14$

21. "Current Population Estimates, Malaysia, 2017-2018". Department of Statistics Malaysia (DSM)

22. N.A. (2010 Jul 22). Selangor, KL and Putrajaya face risk of water shortage by 2014 . The Star Online

23. 'Sivanavandam, H. (2016, Aug 14). Country facing serious water risks. The Star Online.

24. Lai, A. (2017, July 20). MB: Put in rainwater harvesting system for future developments. The Star Online.

25. A. Jalil, H. (2018, Mar 11). Selangor's dangerous politics of water. New Straits Times.

26. 'Session 1 Water Resources Management'. (2014 Aug 26). Department of Irrigation and Drainage. Retrieved from http://gabfoundation.org/business_programme/upload/Session_1_WAT ER_RESOURCES_MANAGEMENT.pdf 